(c) American Dairy Science Association, 2005.

\title{
Performance of Dairy Cows as Affected by Prepartum Dietary Carbohydrate Source and Supplementation with Chromium Throughout the Transition Period*
}

\author{
K. L. Smith, ${ }^{1}$ M. R. Waldron, ${ }^{1}$ J. K. Drackley, ${ }^{2}$ M. T. Socha, ${ }^{3}$ and T. R. Overton ${ }^{1}$ \\ ${ }^{1}$ Department of Animal Science, Cornell University, Ithaca, NY 14853 \\ ${ }^{2}$ Department of Animal Sciences, University of Illinois, Urbana 61801 \\ ${ }^{3}$ Zinpro Corporation, Eden Prairie, MN 55344
}

\begin{abstract}
Holstein cows $(n=72)$ entering second or later lactation were used to determine whether productive performance and dry matter intake (DMI) are affected by carbohydrate source in the prepartum diet and chromium-L-methionine (Cr-Met) supplementation throughout the periparturient period. Cows were fed either a TMR with the concentrate portion based on starch-based cereals [high nonfiber carbohydrate $(\mathrm{NFC}) ; 1.59 \mathrm{Mcal} / \mathrm{kg}$ of net energy for lactation $\left(\mathrm{NE}_{\mathrm{L}}\right)$, $14.4 \%$ crude protein (CP), $40.3 \% \mathrm{NFC]}$ or a TMR with the concentrate portion based on nonforage fiber sources (low NFC; $1.54 \mathrm{Mcal} / \mathrm{kg} \mathrm{NE} \mathrm{L}, 14.5 \% \mathrm{CP}, 33.6 \%$ NFC) from $21 \mathrm{~d}$ before expected parturition until parturition. After parturition all cows were fed a lactation TMR (1.74 Mcal/kg NE $, 16.5 \% \mathrm{CP}, 40.0 \% \mathrm{NFC}$ ). The Cr-Met was supplemented once daily via gelatin capsule at dosages of $0,0.03$, or $0.06 \mathrm{mg}$ of $\mathrm{Cr} / \mathrm{kg}$ of metabolic body weight. Thus, treatments were in a 2 (carbohydrate source $) \times 3$ (Cr-Met) factorial arrangement. Neither prepartum nor postpartum DMI was affected by prepartum dietary carbohydrate source. Administering increasing amounts of Cr-Met linearly increased milk yield and, subsequently, postpartum DMI. Prepartum carbohydrate source did not affect postpartum milk yield; however, cows fed the low NFC diet tended to yield milk with a lower content of total solids. These data indicate that prepartum carbohydrate source has little influence on performance during the immediate peripartal period, and that increases in milk yield for
\end{abstract}

Received May 4, 2004.

Accepted September 9, 2004.

Corresponding author: T. R. Overton; e-mail: tro2@cornell.edu.

*Supported in part by Zinpro Corporation, Eden Prairie, MN, and in part by the Cornell University Agricultural Experiment Station federal formula funds, Project No. 127453, received from Cooperative State Research, Education, and Extension Service, U.S. Department of Agriculture. Any opinions, findings, conclusions, or recommendations expressed in this publication are those of the authors and do not necessarily reflect the view of the U.S. Department of Agriculture. cows supplemented with Cr-Met are independent of prepartum dietary carbohydrate source.

(Key words: periparturient cow, carbohydrate, chromium)

Abbreviation key: CNCPS = Cornell Net Carbohydrate and Protein System, Cr-Met = chromium-L-methionine, NFFS = nonforage fiber sources.

\section{INTRODUCTION}

Periparturient cows undergo tremendous metabolic adaptations as they transition from pregnancy to lactation (Bell, 1995). As part of these adaptations, cows decrease their voluntary DMI beginning approximately 3 wk before parturition with the magnitude of decrease from $21 \mathrm{~d}$ prepartum through $1 \mathrm{~d}$ prepartum approximating 30\% (Hayirli et al., 2002). This decrease in DMI combined with normal homeorhetic regulatory processes precipitates an increase in circulating NEFA released as a result of net lipid mobilization from adipose tissue, leading to the propensity for triglyceride accumulation in the liver during the periparturient period (Drackley et al., 2001). Indeed, Bertics et al. (1992) reported that cows force-fed through a rumen cannula such that they were not able to decrease their DMI experienced an attenuated increase in circulating NEFA and had lower concentrations of triglycerides in liver compared with control cows that were allowed to decrease their voluntary DMI before parturition. Furthermore, Grummer (1995) and Mashek and Grummer (2003) reported significant positive correlations between prepartum DMI and postpartum DMI that become stronger as the cow approaches parturition. Given this relationship between pre- and postpartum DMI, researchers have explored dietary strategies to increase voluntary DMI during the prepartum period.

Carbohydrate nutrition of dairy cows during the transition period has received substantial research attention during the past several years. Most of the research conducted to date has focused on the NFC content of the diet fed during the prepartum period. Overton and 
Waldron (2004) compiled results from 7 experiments conducted during the past $10 \mathrm{yr}$ that focused on NFC content of the prepartum diet. Most of the studies reported one or more favorable outcomes of including higher concentrations of NFC in the prepartum diet compared with lower concentrations of NFC within each experiment, despite the range of content of NFC in these diets. However, in all of these experiments conducted to examine NFC content of the prepartum diet, NFC content of the prepartum diet was confounded either with energy content (Minor et al., 1998; Mashek and Beede, 2000; Holcomb et al., 2001; Keady et al., 2001; Doepel et al., 2002; Rabelo et al., 2003) or with fat content (Grum et al., 1996) of the prepartum diet. Research has not been conducted to evaluate NFC content of the prepartum diet independent of dietary energy or fat content of the diet.

One potential method to vary NFC content of the prepartum diet without confounding with energy content or fat content would be to include nonforage fiber sources (NFFS) such as beet pulp and soybean hulls in the prepartum diet. Nonforage fiber sources have a higher energy value than most forage (Firkins, 1997), increase fiber digestibility when replacing cereal grains (Cunningham et al., 1993), and have lower NFC content than most starchy cereal grains (NRC, 2001). Concomitant with decreased dietary NFC content as NFFS replace cereal grains in the diet would be an increase in dietary NDF. Feeding diets containing larger proportions of NDF, mostly as forage NDF, results in a less pronounced decrease in DMI as cows approach calving compared with diets containing larger concentrations of starch-based NFC (Coppock et al., 1972; Hayirli et al., 2002).

Mashek and Grummer (2003) determined that the change in DMI from d 21 to $d 1$ prepartum was more strongly correlated than was total DMI during this period with postpartum plasma NEFA concentrations and liver triglyceride accumulation; therefore, it may be important to not only promote high levels of DMI during the prepartum period but also minimize the decrease in DMI that occurs as cows approach parturition. Cows fed prepartum diets high in starch-based NFC may decrease their DMI at a greater rate than cows fed a moderate level of NFC (Minor et al., 1998; Rabelo et al., 2003); including NFFS in the prepartum diet may help to alleviate this decline. Controlled experiments have not been conducted to compare diets in which NFFS replaced starch-based NFC in diets fed during the prepartum period.

Other recent information indicates that supplementation with chromium-L-methionine (Cr-Met) during the periparturient period may increase pre- and postpartum DMI and yields of milk, fat, and lactose in mul- tiparous cows (Hayirli et al., 2001) and increase DMI and milk yield in primiparous cows (Yang et al., 1996). Although the exact mechanism of action remains to be elucidated, Davis and Vincent (1997) propose that chromium enhances postreceptor signaling of the insulin receptor and is important in carbohydrate and lipid metabolism. Chromium inclusion in diets fed to growing lambs, broilers, feeder calves, and feeder pigs, especially in times of stress, has resulted in enhanced performance, increased efficiency, and improved glucose metabolism (Chang and Mowat, 1992; Bunting et al., 1994; Kegley and Spears, 1995; Kitchalong et al., 1995; Lien et al., 1999). It is not known whether the type of diet fed during the transition period affects the responses of cows to supplemental Cr.

As described above, the effects of NFC content of the prepartum diet have not been evaluated independent of overall energy content of the diet, and it is unknown whether the peripartal response of cows to Cr supplementation is independent of dietary carbohydrate source. Therefore, the objective of this experiment was to determine whether peripartal cow performance is affected by carbohydrate source in the diet fed prepartum and $\mathrm{Cr}$ supplementation throughout the periparturient period.

\section{MATERIALS AND METHODS}

\section{Animals, Treatments, and Sampling}

The Cornell University Institutional Animal Care and Use Committee approved all procedures involving animals. Seventy-two pregnant Holstein cows entering their second or greater lactation were assigned to 1 of 6 treatment groups in a $2 \times 3$ factorial arrangement of treatments and housed in tie stalls at the Cornell University Dairy Teaching and Research Center. The $2 \times 3$ factorial arrangement of treatments consisted of prepartum diets based upon either starch-based NFC or NFFS in the concentrate portion of the diet to result in prepartum diets containing high and low concentrations of NFC, respectively, and 3 amounts of Cr supplemented from $21 \mathrm{~d}$ before anticipated calving date through $28 \mathrm{~d}$ postpartum.

Cows were fed 1 of 2 prepartum diets that were formulated using the Cornell Net Carbohydrate and Protein System (CNCPS; Fox et al., 2004) to meet or exceed predicted requirements for energy, protein, minerals, and vitamins (NRC, 2001). However, the source of the carbohydrate in the diet varied such that one diet contained a concentrate mix based upon starch-based NFC and the other diet contained a concentrate mix based upon NFFS. These diets were fed from $21 \mathrm{~d}$ before expected parturition until parturition and then, immediately after parturition, all cows were fed a common 
Table 1. Ingredient and nutrient composition (DM basis) of prepartum and postpartum diets.

\begin{tabular}{|c|c|c|c|}
\hline \multirow[b]{2}{*}{ Ingredient } & \multicolumn{2}{|c|}{ Prepartum diet } & \multirow[b]{2}{*}{ Postpartum } \\
\hline & $\begin{array}{l}\text { High } \\
\text { NFC }\end{array}$ & $\begin{array}{l}\text { Low } \\
\text { NFC }\end{array}$ & \\
\hline Alfalfa silage, $\%$ & 9.5 & 9.5 & 15.8 \\
\hline Corn silage, $\%$ & 30.8 & 27.6 & 23.3 \\
\hline Grass hay, \% & 19.8 & 18.1 & 8.4 \\
\hline Ground shelled corn, \% & 17.7 & 3.7 & 27.0 \\
\hline Whole cottonseeds, \% & $\ldots$ & 2.5 & 6.0 \\
\hline Molasses, \% & 0.9 & 1.0 & $\ldots$ \\
\hline Tallow, \% & 0.9 & 0.9 & $\ldots$ \\
\hline Wheat middlings, $\%$ & 9.6 & 11.0 & . . \\
\hline Beet pulp, \% & $\ldots$ & 9.5 & $\ldots$ \\
\hline Soybean hulls, \% & $\ldots$ & 7.9 & \\
\hline Soybean meal ( $47.5 \%$ CP), \% & 5.9 & 2.8 & 7.7 \\
\hline Expeller soybean meal, $\%$ & 2.6 & 3.7 & 5.8 \\
\hline Urea, \% & $\ldots$ & $\ldots$ & 0.2 \\
\hline $\mathrm{Ca}-\mathrm{PFAD},{ }^{1} \%$ & . . & $\ldots$ & 2.0 \\
\hline Sodium bicarbonate, $\%$ & $\ldots$ & $\ldots$ & 1.3 \\
\hline Mineral and vitamin mix, ${ }^{2} \%$ & 2.3 & 2.0 & 2.6 \\
\hline \multicolumn{4}{|l|}{ Energy and nutrient ${ }^{3}$} \\
\hline $\mathrm{NE}_{\mathrm{L}},{ }^{4} \mathrm{Mcal} / \mathrm{kg}$ & 1.59 & 1.54 & 1.74 \\
\hline $\mathrm{NE}_{\mathrm{L}},{ }^{5} \mathrm{Mcal} / \mathrm{kg}$ & 1.60 & 1.58 & 1.72 \\
\hline NDF, $\%$ & 37.2 & 44.1 & 31.3 \\
\hline $\mathrm{NFC}^{6}, \%$ & 40.3 & 33.6 & 40.0 \\
\hline Starch, \% & 27.7 & 18.0 & 29.0 \\
\hline Crude fat, $\%$ & 4.4 & 4.6 & 4.8 \\
\hline MP supply, ${ }^{5} \mathrm{~g} / \mathrm{d}$ & 1418 & 1433 & 2099 \\
\hline $\mathrm{CP}, \%$ & 14.4 & 14.5 & 16.5 \\
\hline Lignin, \% & 4.6 & 4.6 & 3.9 \\
\hline $\mathrm{Ca}, \%$ & 0.77 & 0.81 & 0.78 \\
\hline $\mathrm{P}, \%$ & 0.35 & 0.34 & 0.35 \\
\hline $\mathrm{K}, \%$ & 1.46 & 1.41 & 1.41 \\
\hline $\mathrm{Mg}, \%$ & 0.34 & 0.35 & 0.31 \\
\hline
\end{tabular}

${ }^{1}$ Calcium salts of palm fatty acid distillate (EnerGII; Bioproducts, Inc. Fairlawn, $\mathrm{OH})$.

${ }^{2}$ Contained $20.0 \% \mathrm{Cl}, 13.0 \% \mathrm{Na}, 10.0 \% \mathrm{Ca}, 8.0 \% \mathrm{Mg}, 8.0 \% \mathrm{~S}, 1.0 \%$ $\mathrm{K}, 0.62 \% \mathrm{Zn}, 0.54 \% \mathrm{Mn}, 0.20 \% \mathrm{Fe}, 0.08 \% \mathrm{Cu}, 551 \mathrm{IU} / \mathrm{g}$ of vitamin $\mathrm{A}$, $132 \mathrm{IU} / \mathrm{g}$ of vitamin D, $3 \mathrm{IU} / \mathrm{g}$ of vitamin $\mathrm{E}$.

${ }^{3}$ Values represent averages of samples composited every $4 \mathrm{wk}$.

${ }^{4}$ Based on weighted averages of values provided by DairyOne Laboratories and calculated according to NRC (2001).

${ }^{5}$ Cornell Net Carbohydrate and Protein System- (CNCPS) predicted based upon measured feedstuff nutrient composition and actual DMI.

${ }^{6} \mathrm{NFC}$ was calculated as: $100-[(\mathrm{NDF}-\mathrm{NDFCP})+\mathrm{CP}+$ ether extract + ash] $($ NRC, 2001).

postpartum diet that was formulated to meet or exceed nutrient requirements recommended by the NRC (NRC, 2001). Ingredient and nutrient composition of the 3 diets fed during the experiment and the dietary ingredients are listed in Tables 1 and 2. Cows were fed for ad libitum intake, with fresh feed provided each morning after milking. Orts were weighed and recorded daily. Water was available at all times.

Cows also were administered $0,0.03$, or $0.06 \mathrm{mg}$ of $\mathrm{Cr} / \mathrm{kg}$ of $\mathrm{BW}^{0.75}$ as Cr-Met. Chromium-L-methionine (10\% $\mathrm{Cr}$ and $90 \%$ Met [wt/wt], MicroPlex 1000, a source which supplied $1000 \mathrm{ppm}$ of chromium from a compound containing 1 atom of chromium and 3 molecules of Met; Zinpro Inc., Eden Prairie, MN) was weighed into gelatin capsules (Torpac Inc., Fairfield, NJ) and given orally as a bolus at $1330 \mathrm{~h}$. The control group received $5 \mathrm{~g} / \mathrm{d}$ of limestone in a gelatin capsule as a placebo. The amount of Cr-Met administered to cows during the prepartum period was based upon their BW measured on one day during d 28 to 21 before expected calving; the amount of Cr-Met administered during the postpartum period was adjusted immediately postpartum based upon their postcalving BW.

Feeds were sampled weekly throughout the experiment, and DM content was determined by drying at $55^{\circ} \mathrm{C}$ until static weight. Amounts of individual feed components in the TMR were adjusted weekly based on changes in the DM content of feed components. Feed samples were analyzed by wet chemistry methods for $\mathrm{CP}, \mathrm{ADF}, \mathrm{NDF}$, ether extract, ash, lignin, neutral detergent insoluble $\mathrm{CP}$, acid detergent insoluble $\mathrm{CP}$, starch, soluble CP, and minerals (Dairy One Cooperative Inc., Ithaca, NY). Forages were sampled weekly and a 4-wk composite sample prepared from the individual weekly samples. Concentrate ingredients were sampled on a monthly basis. Prior to analysis, monthly composite samples of forages and monthly samples of concentrate ingredients were compiled into total experimental composites for each feedstuff.

Body weights and BCS of each animal were recorded on $1 \mathrm{~d}$ each week throughout the study. Body condition scores were assigned using a 5-point system (Wildman et al., 1982) by 2 individuals, and the average of these 2 scores was the assigned value. Daily observations and general health records were maintained throughout the study.

After parturition cows were milked 3 times per day, and yields were recorded at each milking. Milk samples were collected from each milking on $1 \mathrm{~d}$ per week and composited into a single sample for analysis through the 4-wk postpartum treatment period. The composite samples were stored at $4^{\circ} \mathrm{C}$ with a preservative (Bronopol tablet; D\&F Control System, San Ramon, CA) for less than $48 \mathrm{~h}$ until analyzed for fat, protein, and lactose using infrared analysis (AOAC, 2000; method 972.160), and somatic cell count by an optical fluorescent method (AOAC, 2000; method 978.26) (Dairy One Cooperative Inc., Ithaca, NY).

\section{Statistical Analyses}

Before analysis of the data using the MIXED procedure of SAS (SAS Institute, 2001), ANOVA was conducted using the GLM procedure of SAS (SAS Institute, 2001). These results were then used to test assumptions concerning normality, equality of variance of the data, and to identify potential outliers. Studentized residuals 
Table 2. Nutrient composition of dietary ingredients (DM basis).

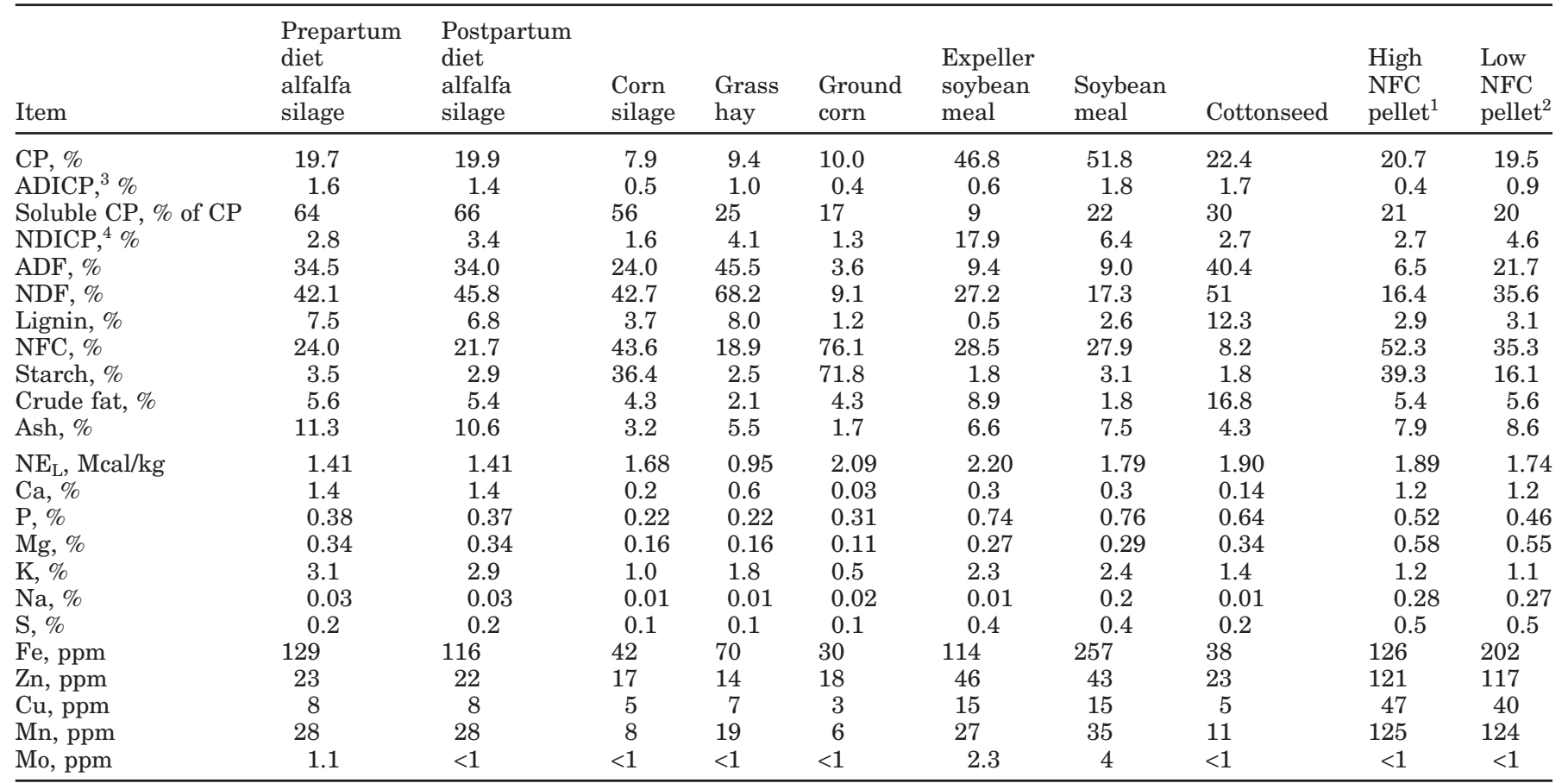

${ }^{1}$ The high NFC pellet contained (\% of DM) $44.0 \%$ ground shelled corn, $24.0 \%$ wheat middlings, $14.7 \%$ soybean meal (47.5\% CP), $6.4 \%$ expeller soybean meal, $5.9 \%$ vitamin mineral mix, $2.3 \%$ tallow, $2.2 \%$ molasses, and $0.5 \%$ pellet binding substance.

${ }^{2}$ The low NFC pellet contained (\% of DM) $24.4 \%$ wheat middlings, $21.0 \%$ beet pulp, $17.5 \%$ soybean hulls, $8.1 \%$ ground shelled corn, $8.1 \%$ expeller soybean meal, $6.3 \%$ soybean meal $(47.5 \% \mathrm{CP}), 5.6 \%$ whole cottonseeds, $4.4 \%$ vitamin mineral mix, $2.2 \%$ molasses, $2.0 \%$ tallow, and $0.4 \%$ pellet binding substance.

${ }^{3} \mathrm{ADICP}=$ Acid detergent insoluble CP.

${ }^{4} \mathrm{NDICP}=$ Neutral detergent insoluble CP.

were plotted against the predicted variable and normalized residuals to assess the data for outliers. The Cook's distance was plotted against observation number, and points with potential to strongly influence the data were crosschecked against studentized residuals $>2$ or $<-2$. Points with studentized residuals $>2.3$ or $<-2.3$ were considered outliers and were automatically removed from the data set. Data with studentized residuals between 2.0 and 2.3 and -2.0 and -2.3 were only removed from the data set if they also exerted strong influence on the data as evidenced by the Cook's distance value relative to the other data. Two cows were removed from the prepartum period and 3 cows were removed from the postpartum period data sets because they were outliers. Cows removed from the prepartum period were as a result of prepartum DMI, and cows removed from the postpartum period were as a result of milk yield $(\mathrm{n}=1)$ or postpartum DMI $(\mathrm{n}=2)$. Cows that were removed from the data set for these measurements were removed for all other measurements.

Daily DMI and milk yield values were used during statistical analysis. However, they were reduced to weekly means for calculations of energy balance (NRC,
2001) and to calculate yields of milk components. Pretreatment values for DMI, BW, and BCS were used as covariates during analysis of covariance applied to their corresponding measurements during the treatment period. ANOVA was conducted using the MIXED procedure of SAS (2001) for a completely randomized design with repeated measures. The model included the effects of carbohydrate source, Cr-Met supplementation, interaction of carbohydrate source and Cr-Met, day, and 2and 3-way interactions of main effects with day. Orthogonal contrasts were used to assess linear and quadratic effects of increasing Cr-Met supply. Least square means are reported throughout, and significance was declared at $P<0.05$; trends were declared at $0.05<P<0.15$.

\section{RESULTS AND DISCUSSION}

The nutrient composition of the prepartum diets was considerably different to investigate the effects of varying NFC content while keeping the diets essentially isocaloric. The diets had similar calculated $\mathrm{NE}_{\mathrm{L}}$ (high NFC: $1.59 \mathrm{Mcal} / \mathrm{kg}$; low NFC: $1.54 \mathrm{Mcal} / \mathrm{kg}$ ) and fat (high NFC: $4.4 \%$; low NFC: $4.6 \%$ ) content; CNCPS-pre- 
Table 3. Pre- and postpartum DMI, BCS, BW, net energy balance (NEB) and yield and composition of milk from cows fed prepartum diets differing in NFC content.

\begin{tabular}{|c|c|c|c|c|}
\hline \multirow[b]{2}{*}{ Item } & \multicolumn{2}{|c|}{ Prepartum diet ${ }^{1}$} & \multirow[b]{2}{*}{$\mathrm{SE}$} & \multirow[b]{2}{*}{$P$-value } \\
\hline & $\begin{array}{l}\text { High } \\
\text { NFC }\end{array}$ & $\begin{array}{l}\text { Low } \\
\text { NFC }\end{array}$ & & \\
\hline \multicolumn{5}{|l|}{ Prepartum } \\
\hline DMI, kg/d & 13.7 & 13.8 & 0.2 & 0.77 \\
\hline DMI, $\%$ of BW & 1.9 & 1.9 & 0.1 & 0.95 \\
\hline Change in DMI, \% of $\mathrm{BW}^{2}$ & -0.70 & -0.78 & 0.08 & 0.47 \\
\hline $\mathrm{BCS}^{3}$ & 3.32 & 3.32 & 0.02 & 0.75 \\
\hline $\mathrm{BW},{ }^{4} \mathrm{~kg}$ & 724 & 723 & 2 & 0.95 \\
\hline $\mathrm{NEB},{ }^{5} \mathrm{Mcal} / \mathrm{d}$ & 6.9 & 6.5 & 0.4 & 0.36 \\
\hline \multicolumn{5}{|l|}{ Postpartum } \\
\hline $\mathrm{DMI}, \mathrm{kg} / \mathrm{d}$ & 18.7 & 19.2 & 0.3 & 0.22 \\
\hline BCS & 2.84 & 2.86 & 0.04 & 0.70 \\
\hline BW, kg & 621 & 628 & 5 & 0.29 \\
\hline $\mathrm{NEB},{ }^{6} \mathrm{Mcal} / \mathrm{d}$ & -8.8 & -7.6 & 0.6 & 0.11 \\
\hline Milk, kg/d & 40.6 & 41.8 & 0.7 & 0.17 \\
\hline $3.5 \% \mathrm{FCM}, \mathrm{kg} / \mathrm{d}$ & 46.2 & 46.6 & 0.7 & 0.62 \\
\hline Fat, \% & 4.43 & 4.30 & 0.08 & 0.28 \\
\hline Fat, kg/d & 1.76 & 1.76 & 0.04 & 0.94 \\
\hline True protein, \% & 3.35 & 3.21 & 0.08 & 0.25 \\
\hline True protein, kg/d & 1.32 & 1.31 & 0.05 & 0.96 \\
\hline Lactose, \% & 4.67 & 4.63 & 0.04 & 0.48 \\
\hline Lactose, kg/d & 1.90 & 1.95 & 0.05 & 0.47 \\
\hline Total solids, \% & 13.40 & 13.10 & 0.13 & 0.11 \\
\hline Total solids, kg/d & 5.36 & 5.42 & 0.12 & 0.73 \\
\hline $\mathrm{SCC}, \times 1000$ & 361 & 446 & 111 & 0.58 \\
\hline MUN, mg/dL & 14.1 & 14.2 & 0.4 & 0.94 \\
\hline
\end{tabular}

${ }^{1}$ Cows received a prepartum diet with the concentrate portion consisting of high NFC (control treatment; $\mathrm{n}=34$ cows) or low NFC (dietary treatment; $\mathrm{n}=38$ cows).

${ }^{2}$ Change in DMI expressed as percentage of BW from $18 \mathrm{~d}$ before parturition through $1 \mathrm{~d}$ before parturition.

${ }^{3}$ Cows were scored on a 5 -point scale by 2 individuals on one day each week throughout the study and values averaged.

${ }^{4}$ Cows were weighed on one day each week throughout the study.

${ }^{5}$ Net energy balance: calculated based on NRC (2001). Prepartum $\mathrm{NEB}=\left(\mathrm{DMI} \times \mathrm{NE}_{\mathrm{L}}\right.$ diet $)-\left[\left(\mathrm{BW}^{0.75} \times 0.08\right)+(((2 \times 0.00159 \times\right.$ Days Pregnant - 0.0353) $\times($ Calf BW/45)/0.14) $\times 0.64)]$.

${ }^{6} \mathrm{Net}$ energy balance: calculated based on NRC (2001). Postpartum $\mathrm{NEB}=\left(\mathrm{DMI} \times \mathrm{NE}_{\mathrm{L}}\right.$ diet $)-\left[\left(0.08 \times \mathrm{BW}^{0.75}\right)+((0.0929 \times \mathrm{Fat}+0.0563\right.$ $\times$ Protein $+0.0395 \times$ Lactose $) \times$ milk yield $)]$.

dicted metabolizable protein supplied were also similar (high NFC: $1418 \mathrm{~g} / \mathrm{d}$, low NFC: $1433 \mathrm{~g} / \mathrm{d}$ ). The prepartum diet containing a high proportion of starch-based NFC had higher NFC (40.3 vs. 33.6\%) and starch (27.7 vs. $18.0 \%$ ) content and lower NDF (37.2 vs. $44.1 \%$ ) content than the prepartum diet containing low NFC with the concentrate portion based upon NFFS. Results of statistical comparisons are reported as the main effects of carbohydrate source and Cr-Met supplementation because all 2-way interactions of prepartum dietary carbohydrate source and $\mathrm{Cr}$ supplementation and 3way interactions of these main effects with time were not significant. Trends for 3 -way interactions will be discussed later in the text where appropriate. Prepartum DMI averaged approximately $13.8 \mathrm{~kg} / \mathrm{d}$ and $1.9 \%$ of BW (Table 3). Prepartum and postpartum DMI (Ta-

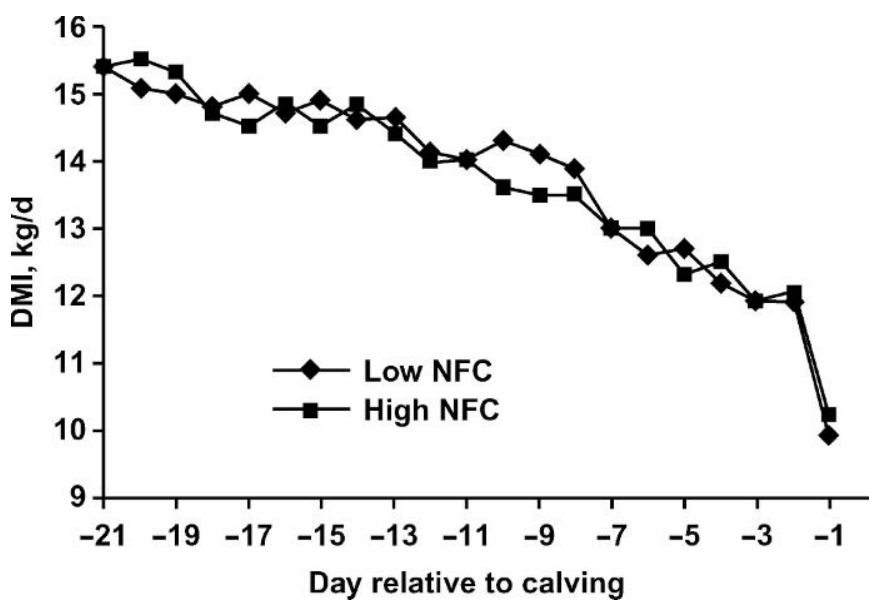

Figure 1. Temporal pattern of DMI during the prepartum period for cows fed prepartum diets varying in NFC content. Values are least square means, $\mathrm{n}=34$ for high NFC and $\mathrm{n}=38$ for low NFC; SEM averaged $0.5 \mathrm{~kg} / \mathrm{d}$; the $P$-value for the interaction of treatment $\times$ day was 0.57 .

ble 3; Figure 1), prepartum DMI expressed as a percentage of $\mathrm{BW}$, and the change in DMI as a percentage of BW from $18 \mathrm{~d}$ before parturition until $1 \mathrm{~d}$ before parturition were not affected $(P>0.15)$ by source of carbohydrate in the prepartum diet (Table 3). Similarly, neither prepartum nor postpartum BCS or BW was affected $(P>0.15)$ by prepartum carbohydrate source (Table 3). Prepartum calculated net energy balance was not affected by prepartum carbohydrate source, but cows fed the low NFC diet based upon NFFS prepartum tended $(P<0.11)$ to be in a less negative energy balance during the postpartum period than cows fed a prepartum diet with concentrates based on NFC. Prepartum carbohydrate source did not affect postpartum milk yield, milk component yields, and most milk component percentages $(P>0.15)$; however, cows fed the high NFC diet during the prepartum period tended $(P<0.11)$ to have a higher percentage of total solids in milk (Table 3 ). The incidences of health disorders by cows fed high or low NFC in the prepartum diet are reported in Table 4. The number of cows per prepartum dietary treatment was insufficient to statistically assess these variables, and this information is reported for information only.

Overton and Waldron (2004) compiled the results from 7 experiments conducted during the past $10 \mathrm{yr}$ that focused on NFC content of the prepartum diet. Despite the range in NFC content of the diet, most researchers reported positive effects of feeding a higher NFC diet compared with a paired lower NFC diet within each experiment. In this experiment, feeding two relatively isocaloric prepartum diets that differed in NFC content resulted in virtually no differences in periparturient performance, indicating that NFC content of the 
Table 4. Incidence of health-related disorders during the first $21 \mathrm{~d}$ of lactation in cows fed prepartum diets differing in NFC content.

\begin{tabular}{llllll}
\hline & \multicolumn{4}{c}{ Prepartum diet $^{1}$} \\
\cline { 2 - 3 } \cline { 5 - 6 } \cline { 5 - 6 } Disorder & \multicolumn{2}{c}{ High NFC } & & Low NFC \\
\cline { 2 - 3 } \cline { 5 - 6 } & No. of & $\begin{array}{l}\text { No. of } \\
\text { episodes }\end{array}$ & & $\begin{array}{l}\text { No. of } \\
\text { cows }\end{array}$ & $\begin{array}{l}\text { No. of } \\
\text { episodes }\end{array}$ \\
\hline Twins & 2 & 2 & & 4 & 4 \\
Hypocalcemia & 3 & 3 & & 2 & 2 \\
Retained placenta & 3 & 3 & & 3 & 3 \\
Displaced abomasums & 2 & 2 & & 3 & 3 \\
Ketosis & 5 & 7 & & 2 & 2 \\
Mastitis & 5 & 5 & & 6 & 6 \\
\hline
\end{tabular}

${ }^{1}$ Cows received a prepartum diet with the concentrate portion consisting of high NFC (control treatment; $\mathrm{n}=34$ cows) or low NFC (dietary treatment; $\mathrm{n}=38$ cows).

prepartum diet probably is not as important as is overall energy content from fermentable carbohydrate sources or the pattern of energy intake preceding parturition. Other researchers have investigated NFC nutrition of the prepartum dairy cow by varying the fermentability of the dietary NFC. Dann et al. (1999) increased carbohydrate fermentability by including steam-flaked corn in the close-up diet and reported that cows produced more milk when fed steam-flaked corn during the prepartum period. These cows had similar patterns of decline in prepartum DMI to those of cows reported in the literature (Hayirli et al., 2002). In our study cows during the prepartum period declined in DMI by about $33 \%$ from $d-21$ to $d-1$, similar to literature estimates (Hayirli et al., 2002), but with only 55\% of that decline occurring during the final week of gestation as compared with $89 \%$ of the decline reported elsewhere (Hayirli et al., 2002).

Hayirli et al. (2002) concluded that cows fed high $\mathrm{NDF}$ diets $(>40 \%)$ during the prepartum period have decreased DMI during this period compared with cows fed diets containing lower concentrations of NDF. The low NFC diet fed during the prepartum period had a high concentration of NDF (44\%) compared with the high NFC diet (37\%); however, there were no significant differences in DMI or the decrease in DMI prior to calving, suggesting that the form of the NDF (and thereby metabolizable energy) is an important determinant of responses of cows to high NDF diets fed during the prepartum period. This same reasoning can be used to explain our results relative to NFC content of the diet. Contrary to results reported by Rabelo et al. (2003) and Minor et al. (1998), cows fed a prepartum diet lower in NFC did not have lower prepartum DMI or different patterns of decline in DMI before calving. Thus, the suggestions of Minor et al. (1998) and Rabelo et al. (2003) that feeding high NFC diets result in increased rates of decline compared with lower NFC diets may be a phenomenon associated with overall energy provided from fermentable carbohydrate sources rather than the NFC content of the diet per se.

Pickett et al. (2003) reported an increase in prepartum DMI with the inclusion of NFFS in the prepartum diet; however, they replaced $28 \%$ of the forage in the diet with NFFS, thus potentially affecting digestion kinetics, passage rate, and NDF digestibility of the prepartum diet as compared with the conventional diet that contained a higher concentration of forage. Although we did not measure digestibilities, digestion kinetics, or passage rate in our experiment, we speculate that one of the reasons that we may not have detected differences in DMI when we replaced starchbased NFC with NFFS in pelleted concentrate mixtures may relate to less potential for differences in ruminal dynamics due to smaller changes in physically effective NDF supply between diets in our experiment compared with those of Pickett et al. (2003).

Supplementation with Cr-Met did not affect DMI or DMI as a percentage of BW during the prepartum period (Table 5); however, administering increasing amounts of Cr-Met linearly increased $(P<0.01)$ DMI of dairy cows during the postpartum period (Table 5; Figure 2). Administering increasing amounts of Cr-Met linearly increased $(P<0.01)$ prepartum BCS and postpartum BW of cows $(P<0.01)$, but differences $(P>$ $0.15)$ in prepartum BW and postpartum BCS were not significant (Table 5). There was no effect of Cr-Met administration on pre- or postpartum calculated net energy balance. Given the relatively small magnitude of differences in BCS and BW and the lack of a significant effect of treatment on calculated net energy balances during both the prepartum and postpartum periods, it is likely that effects of Cr-Met administration on actual energy balance in this experiment were minimal.

Administering increasing amounts of Cr-Met to cows linearly increased $(P<0.05)$ yields of milk (Table 5; Figure 3) and 3.5\% FCM (Table 5), but there was no effect of periparturient Cr-Met supplementation on milk composition. The incidences of health disorders by cows administered increasing amounts of Cr-Met from $21 \mathrm{~d}$ before expected parturition through $28 \mathrm{~d}$ postpartum are reported in Table 6 . The number of cows per treatment is insufficient to statistically assess these variables and this information is reported for information only.

Subiyatno et al. (1996) reported that Cr supplementation did not affect DMI and milk production of periparturient cows; however, Yang et al. (1996) reported increased DMI and increased milk yield in response to feeding Cr-Met to primiparous cows. Hayirli et al. (2001) and Besong et al. (1996) reported increased milk yield and, subsequently, postpartum DMI when cows 
Table 5. Pre- and postpartum DMI, BCS, BW, net energy balance (NEB), and yield and composition of milk from cows fed increasing amounts of Cr-Met from $21 \mathrm{~d}$ prepartum through $28 \mathrm{~d}$ postpartum.

\begin{tabular}{|c|c|c|c|c|c|c|}
\hline \multirow[b]{2}{*}{ Item } & \multicolumn{3}{|c|}{$\mathrm{Cr},{ }^{1} \mathrm{mg} / \mathrm{kg} \mathrm{BW}{ }^{0.75}$} & \multirow[b]{2}{*}{$\mathrm{SE}$} & \multicolumn{2}{|c|}{$P$-value } \\
\hline & 0 & 0.03 & 0.06 & & Linear & Quadratic \\
\hline \multicolumn{7}{|l|}{ Prepartum } \\
\hline DMI, kg/d & 13.6 & 13.9 & 13.6 & 0.2 & 0.97 & 0.21 \\
\hline DMI, \% of BW & 1.9 & 1.9 & 1.9 & 0.1 & 0.91 & 0.19 \\
\hline Change in DMI, $\%$ of $\mathrm{BW}^{2}$ & -0.74 & -0.69 & -0.79 & 0.10 & 0.74 & 0.59 \\
\hline $\mathrm{BCS}^{3}$ & 3.27 & 3.32 & 3.38 & 0.03 & 0.01 & 0.89 \\
\hline $\mathrm{BW},{ }^{4} \mathrm{~kg}$ & 722 & 724 & 724 & 3 & 0.57 & 0.74 \\
\hline $\mathrm{NEB},{ }^{5} \mathrm{Mcal} / \mathrm{d}$ & 6.5 & 7.1 & 6.5 & 0.4 & 0.91 & 0.28 \\
\hline \multicolumn{7}{|l|}{ Postpartum } \\
\hline DMI, kg/d & 18.2 & 18.9 & 19.7 & 0.4 & 0.01 & 0.91 \\
\hline $\mathrm{BCS}$ & 2.84 & 2.83 & 2.89 & 0.05 & 0.41 & 0.50 \\
\hline $\mathrm{BW}, \mathrm{kg}$ & 614 & 620 & 639 & 6 & 0.01 & 0.37 \\
\hline $\mathrm{NEB},{ }^{6} \mathrm{Mcal} / \mathrm{d}$ & -8.3 & -8.1 & -8.3 & 0.7 & 0.99 & 0.80 \\
\hline Milk, kg/d & 40.3 & 40.5 & 42.8 & 0.8 & 0.03 & 0.29 \\
\hline $3.5 \% \mathrm{FCM}, \mathrm{kg} / \mathrm{d}$ & 45.4 & 46.0 & 47.8 & 0.9 & 0.05 & 0.58 \\
\hline Fat, \% & 4.36 & 4.41 & 4.33 & 0.11 & 0.85 & 0.62 \\
\hline Fat, kg/d & 1.72 & 1.76 & 1.81 & 0.04 & 0.19 & 0.88 \\
\hline True protein, \% & 3.34 & 3.37 & 3.15 & 0.11 & 0.22 & 0.34 \\
\hline True protein, kg/d & 1.30 & 1.32 & 1.32 & 0.06 & 0.83 & 0.83 \\
\hline Lactose, \% & 4.65 & 4.68 & 4.62 & 0.05 & 0.66 & 0.39 \\
\hline Lactose, $\mathrm{kg} / \mathrm{d}$ & 1.88 & 1.91 & 1.98 & 0.05 & 0.21 & 0.75 \\
\hline Total solids, \% & 13.3 & 13.4 & 13.0 & 0.2 & 0.19 & 0.28 \\
\hline Total solids, $\mathrm{kg} / \mathrm{d}$ & 5.30 & 5.37 & 5.50 & 0.14 & 0.32 & 0.85 \\
\hline $\mathrm{SCC}$ & 355 & 360 & 495 & 135 & 0.46 & 0.69 \\
\hline MUN & 14.1 & 13.9 & 14.5 & 0.5 & 0.53 & 0.57 \\
\hline
\end{tabular}

${ }^{1}$ Cows received $0(\mathrm{n}=22), 0.03(\mathrm{n}=25)$, and $0.06(\mathrm{n}=25) \mathrm{mg}$ of $\mathrm{Cr} / \mathrm{kg}$ of $\mathrm{BW}^{0.75}$ as Cr-Met.

${ }^{2}$ Change in DMI as percentage of BW from $18 \mathrm{~d}$ before parturition through one day before parturition.

${ }^{3}$ Cows were scored on a 5 -point scale by 2 individuals on one day each week throughout the study and values averaged.

${ }^{4}$ Cows were weighed on one day each week throughout the study.

${ }^{5}$ Net energy balance: calculated based on NRC $(2001)$. Prepartum NEB $=\left(\mathrm{DMI} \times \mathrm{NE}_{\mathrm{L}}\right.$ diet $)-\left[\left(\mathrm{BW}^{0.75} \times\right.\right.$ $0.08)+(((2 \times 0.00159 \times$ Days Pregnant -0.0353$) \times($ Calf BW/45 $) / 0.14) \times 0.64)]$.

${ }^{6}$ Net energy balance: calculated based on NRC (2001). Postpartum NEB $=\left(\mathrm{DMI} \times \mathrm{NE}_{\mathrm{L}}\right.$ diet $)-[(0.08 \times$ $\left.\mathrm{BW}^{0.75}\right)+((0.0929 \times$ Fat $+0.0563 \times$ Protein $+0.0395 \times$ Lactose $) \times$ Milk yield $\left.)\right]$.

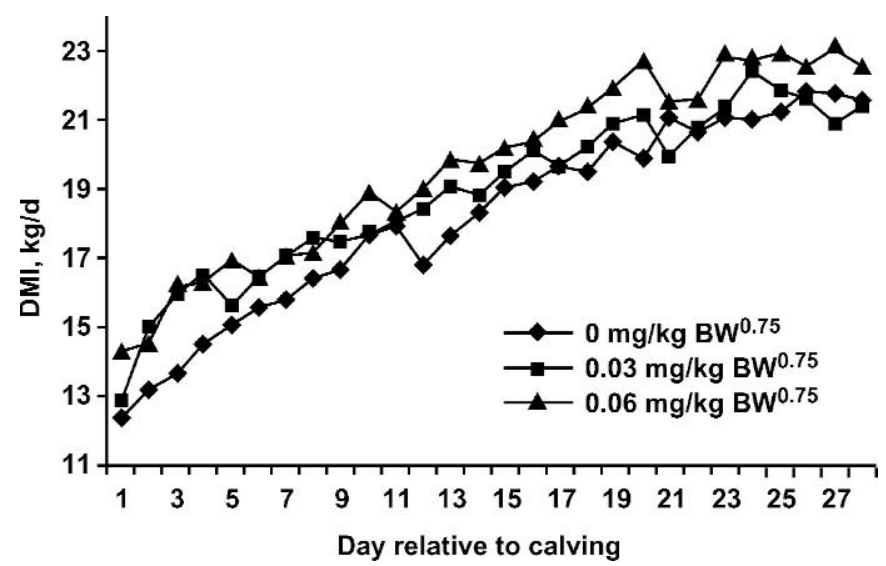

Figure 2. Temporal pattern of DMI during the postpartum period for cows administered increasing amounts of chromium as Cr-Met. Values are least square means, $\mathrm{n}=22$ for control, $\mathrm{n}=25$ for $\mathrm{Cr}$ at $0.03 \mathrm{mg} / \mathrm{kg} \mathrm{BW} \mathrm{BW}^{0.75}$ and $\mathrm{n}=25$ for $\mathrm{Cr}$ at $0.06 \mathrm{mg} / \mathrm{kg} \mathrm{BW}^{0.75} ; \mathrm{SEM}$ averaged $1.3 \mathrm{~kg} / \mathrm{d}$; the $P$-value for the linear effect of chromium was 0.01 and that for the treatment $\times$ day interaction was 0.03 .

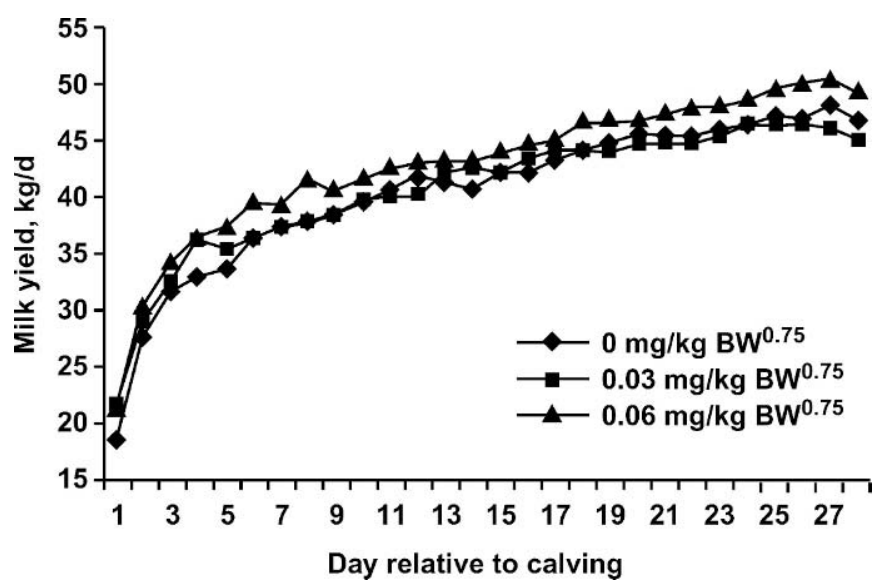

Figure 3. Temporal pattern of milk yield during the postpartum period for cows administered increasing amounts of chromium as $\mathrm{Cr}$ Met. Values are least square means, $\mathrm{n}=22$ for control, $\mathrm{n}=25$ for $\mathrm{Cr}$ at $0.03 \mathrm{mg} / \mathrm{kg} \mathrm{BW}^{0.75}$ and $\mathrm{n}=25$ for $\mathrm{Cr}$ at $0.06 \mathrm{mg} / \mathrm{kg} \mathrm{BW}^{0.75} ; \mathrm{SEM}$ averaged $0.7 \mathrm{~kg} / \mathrm{d}$; the $P$-value for the linear effect of Cr was 0.03 and that for the treatment $\times$ day interaction was 0.58 . 
Table 6. Incidence of health-related disorders during the first $21 \mathrm{~d}$ of lactation in cows fed increasing amounts of Cr-Met from $21 \mathrm{~d}$ prepartum through $28 \mathrm{~d}$ postpartum.

\begin{tabular}{|c|c|c|c|c|c|c|}
\hline \multirow[b]{3}{*}{ Disorder } & \multicolumn{6}{|c|}{$\mathrm{Cr},{ }^{1}$} \\
\hline & \multicolumn{2}{|c|}{$0 \mathrm{mg} / \mathrm{kg} \mathrm{BW} \mathrm{B}^{0.75}$} & \multicolumn{2}{|c|}{$0.03 \mathrm{mg} / \mathrm{kg} \mathrm{BW}{ }^{0.75}$} & \multicolumn{2}{|c|}{$0.06 \mathrm{mg} / \mathrm{kg} \mathrm{BW}{ }^{0.75}$} \\
\hline & $\begin{array}{l}\text { No. of } \\
\text { cows }\end{array}$ & $\begin{array}{l}\text { No. of } \\
\text { episodes }\end{array}$ & $\begin{array}{l}\text { No. of } \\
\text { cows }\end{array}$ & $\begin{array}{l}\text { No. of } \\
\text { episodes }\end{array}$ & $\begin{array}{l}\text { No. of } \\
\text { cows }\end{array}$ & $\begin{array}{l}\text { No. of } \\
\text { episodes }\end{array}$ \\
\hline Twins & 3 & 3 & 2 & 2 & 1 & 1 \\
\hline Hypocalcemia & 2 & 2 & 2 & 2 & 1 & 1 \\
\hline Retained placenta & 2 & 2 & 2 & 2 & 2 & 2 \\
\hline Displaced abomasums & 4 & 4 & 1 & 1 & 0 & 0 \\
\hline Ketosis & 1 & 1 & 3 & 3 & 3 & 5 \\
\hline Mastitis & 4 & 4 & 3 & 3 & 4 & 4 \\
\hline
\end{tabular}

${ }^{1}$ Cows received $0(n=22), 0.03(n=25)$, or $0.06(n=25) \mathrm{mg}$ of $\mathrm{Cr} / \mathrm{kg} \mathrm{BW}{ }^{0.75}$ as Cr-Met.

were fed supplemental Cr during the periparturient period. Hayirli et al. (2001) and Yang et al. (1996) suggested that the positive responses to $\mathrm{Cr}$ supplementation measured in their experiments might have been caused by an alleviation of a dietary Cr deficiency. At the present time, the chromium requirements of dairy cows are not known (NRC, 2001) and therefore we cannot determine whether the positive performance responses to $\mathrm{Cr}$ administration in our experiment and those of others were due to alleviation of a deficiency or some other factor related to the physiological mode of action of $\mathrm{Cr}$.

Although the 2-way interactions of the main effects was not significant in this experiment, trends for 3-way interactions of carbohydrate source, Cr-Met, and time existed $(P<0.15)$ for the percentage and yield of true protein in milk, the percentage of lactose in milk, MUN content of milk, and BCS during the prepartum period. Examination of the temporal patterns for these variables (data not shown) indicated that the postpartum differences in milk composition were confined to the first week postpartum, and the prepartum differences in BCS were $<0.2 \mathrm{BCS}$ units, thus limiting the meaningfulness of these differences, in our opinion. We do not believe that these interactions were biologically significant. In addition, there was a trend $(P<0.14)$ for a carbohydrate $\times$ chromium interaction for milk fat percentage such that cows fed the prepartum diet high in NFC, when fed increasing amounts of chromium, had higher milk fat percentages (high NFC: $4.25,4.54$, and $4.52 \%$; low NFC: $4.47,4.28,4.14 \%$ ) when fed $0,0.03$, or $0.06 \mathrm{mg} \mathrm{Cr} / \mathrm{kg} \mathrm{BW}{ }^{0.75}$, respectively. Like the other interactions, most differences occurred during the first week postpartum, and the biological significance of these differences is modest.

\section{CONCLUSIONS}

Varying the NFC content of the diet fed during the prepartum period independently of the dietary energy content, fat content, or predicted metabolizable protein supply resulted in virtually no difference in performance of dairy cows during the prepartum period, suggesting that overall amount of energy provided by fermentable carbohydrate sources is likely a more important determinant of peripartal performance than content of NFC per se. Administration of Cr-Met during the periparturient period significantly increased DMI and yields of milk and $3.5 \% \mathrm{FCM}$ during the postpartum period. These results are consistent with other published literature indicating that $\mathrm{Cr}$ supplementation during the periparturient period results in increased DMI and milk yield of dairy cows. Furthermore, our results also suggest that the carbohydrate composition of the diet fed during the prepartum period does not affect the response of cows to supplemental Cr.

\section{ACKNOWLEDGMENTS}

The assistance of the following students and colleagues at Cornell University in implementing the study is gratefully acknowledged and appreciated: M. Partridge, T. Muscato, R. Ehrhardt, A. Kulick, G. Johnson, L. Ruzzi, A. Rauf, K. James, and the staff at the Cornell University Dairy Teaching and Research Center.

\section{REFERENCES}

Association of Official Analytical Chemists. 2000. Official Methods of Analysis. 17th ed. AOAC, Gaithersburg, MD.

Bell, A. W. 1995. Regulation of organic nutrient metabolism during transition from late pregnancy to early lactation. J. Anim. Sci. 73:2804-2819.

Bertics, S. J., R. R. Grummer, C. Cadorniga-Valino, and E. Stoddard. 1992. Effect of prepartum dry matter intake on liver triglyceride concentration and early lactation. J. Dairy Sci. 75:1914-1922.

Besong, S., J. A. Jackson, D. S. Trammell, and V. Akay. 1996. Influence of supplemental chromium on concentrations of liver triglyceride, blood metabolites, and rumen VFA profile in steers fed a moderately high fat diet. J. Dairy Sci. 84:1679-1685.

Bunting, L. D., J. M. Fernandez, D. L. Thompson, Jr., and L. L. Southern. 1994. Influence of chromium picolinate on glucose us- 
age and metabolic criteria in growing Holstein calves. J. Anim. Sci. 72:1591-1599.

Chang, X., and D. N. Mowat. 1992. Supplemental chromium for stressed and growing feeder calves. J. Anim. Sci. 70:559-565.

Coppock, C. E., C. H. Noller, S. A. Wolfe, C. J. Callahan, and J. S Baker. 1972. Effect of forage-concentrate ratio in complete feeds fed ad libitum on energy intake in relation to requirements by dairy cows. J. Dairy Sci. 57:783-789.

Cunningham, K. D., M. J. Cecava, and T. R. Johnson. 1993. Nutrient digestion, nitrogen, and amino acid flows in lactating cows fed soybean hulls in place of forage or concentrate. J. Dairy Sci. 76:3523-3535.

Dann, H. M., G. A. Varga, and D. E. Putnam. 1999. Improving energy supply to late gestation and early postpartum dairy cows. J. Dairy Sci. 82:1765-1778.

Davis, C. M., and J. B. Vincent. 1997. Chromium oligopeptide activates insulin receptor tyrosine kinase activity. Biochemistry 36:4382-4385.

Doepel, L., H. Lapierre, and J. J. Kennelly. 2002. Peripartum performance and metabolism of dairy cows in response to prepartum energy and protein intake. J. Dairy Sci. 85:2315-2334.

Drackley, J. K., T. R. Overton, and G. N. Douglas. 2001. Adaptations of glucose and long-chain fatty acid metabolism in liver of dairy cows during the periparturient period. J. Dairy Sci. 84:E100E112.

Firkins, J. L. 1997. Effects of feeding nonforage fiber sources on site of fiber digestion. J. Dairy Sci. 80:1426-1437.

Fox, D. G., L. O. Tedeschi, T. P. Tylutki, J. B. Russell, M. E. Van Amburgh, L. E. Chase, A. N. Pell, and T. R. Overton. 2004. The Cornell Net Carbohydrate and Protein System for evaluating herd nutrition and nutrient excretion. Anim. Feed Sci. Technol. 112:29-78

Grum, D. E., J. K. Drackley, R. S. Younker, D. W. LaCount, and J. J. Veenhuizen. 1996. Nutrition during the dry period and hepatic lipid metabolism of periparturient dairy cows. J. Dairy Sci. 79:1850-1864.

Grummer, R. R. 1995. Impact of changes in organic nutrient metabolism on feeding the transition dairy cow. J. Anim. Sci. 73:2820-2833.

Hayirli, A., D. R. Bremmer, S. J. Bertics, M. T. Socha, and R. R. Grummer. 2001. Effect of chromium supplementation on production and metabolic parameters in periparturient dairy cows. J. Dairy Sci. 84:1218-1230.

Hayirli, A., R. R. Grummer, E. V. Nordheim, and P. M. Crump. 2002. Animal and dietary factors affecting feed intake during the prefresh transition period in Holsteins. J. Dairy Sci. 85:3430 3443.

Holcomb, C. S., H. H. Van Horn, H. H. Head, M. B. Hall, and C. J. Wilcox. 2001. Effects of prepartum dry matter intake and forage percentage on postpartum performance of lactating dairy cows. J. Dairy Sci. 84:2051-2058.
Keady, T. W. J., C. S. Mayne, D. A. Fitzpatrick, and M. A. McCoy. 2001. Effect of concentrate feed level in late gestation on subsequent milk yield, milk composition, and fertility of dairy cows. J. Dairy Sci. 84:1468-1479.

Kegley, E. B., and J. W. Spears. 1995. Immune response, glucose metabolism, and performance of stressed feeder calves fed inorganic or organic chromium. J. Anim. Sci. 73:2721-2726.

Kitchalong, L., J. M. Fernandez, L. D. Bunting, L. L. Southern, and T. D. Bidner. 1995. Influence of chromium tripicolinate on glucose metabolism and nutrient partitioning in growing lambs. J. Anim. Sci. 73:2694-2705.

Lien, T. F., Y. M. Horng, and K. H. Yang. 1999. Performance, serum characteristics, carcass traits and lipid metabolism of broilers as affected by supplement of chromium picolinate. Br. Poult. Sci. 40:357-363.

Mashek, D. G., and D. K. Beede. 2000. Peripartum responses of dairy cows to partial substitution of corn silage with corn grain in diets fed during the late dry period. J. Dairy Sci. 83:2310-2318.

Mashek, D. G., and R. R. Grummer. 2003. Feeding pre-fresh transition cows: Should we maximize feed intake or minimize feed intake depression? J. Dairy Sci. 86(Suppl. 1):11. (Abstr.)

Minor, D. J., S. L. Trower, B. D. Strang, R. D. Shaver, and R. R. Grummer. 1998. Effects of nonfiber carbohydrate and niacin on periparturient metabolic status and lactation of dairy cows. J. Dairy Sci. 81:189-200.

National Research Council. 2001. Nutrient Requirements of Dairy Cattle. 7th rev. ed. Natl. Acad. Sci., Washington, DC.

Overton, T. R., and M. R. Waldron. 2004. Nutritional management of transition dairy cows: Strategies to optimize metabolic health. J. Dairy Sci. 87(E. Suppl.):E105-E119.

Pickett, M. M., T. W. Cassidy, P. R. Tozer, and G. A. Varga. 2003. Effect of prepartum dietary carbohydrate source and monensin on dry matter intake, milk production, and blood metabolites of transition dairy cows. J. Dairy Sci. 86(Suppl. 1):10. (Abstr.)

Rabelo, E., R. L. Rezende, S. J. Bertics, and R. R. Grummer. 2003. Effects of transition diets varying in dietary energy density on lactation performance and ruminal parameters of dairy cows. J. Dairy Sci. 86:916-925

SAS User's Guide: Statistics, Version 8 Edition. 2001. SAS Inst. Inc. Cary, NC.

Subiyatno, A., D. N. Mowat, and W. Z. Yang. 1996. Metabolite and hormonal responses to glucose or propionate infusions in periparturient dairy cows supplemented with chromium. J. Dairy Sci. 79:1436-1445.

Wildman, E. E., G. M. Jones, P. E. Wagner, R. L. Boman, H. F. Trout, and T. N. Lesch. 1982. A dairy cow body condition scoring system and its relationship to selected production variables in high producing Holstein dairy cattle. J. Dairy Sci. 65:495-501.

Yang, W. Z., D. N. Mowat, A. Subiyatno, and R. M. Liptrap. 1996. Effects of chromium supplementation on early lactation performance of Holstein cows. Can. J. Anim. Sci. 221-230. 